\title{
THE ORDOVICIAN RADIATIONS OF BIVALVIA REVISITED
}

Claude BABIN, Centre des Sciences de la Terre, Université Claude Bernard-Lyon I, 43, bd du 11 novembre, 69622 Villeurbanne Cedex, France.

Examination of the evolution of bivalves on Gondawanan platforms of Ordovician age reveals a pattern of waning and waxing. These first radiations spanning the Upper Tremadoc-Llandeilo time interval were followed by a decline during the Upper Ordovician, which raises the question of evolutionary modes and causes of this pattern.

The comparison of these Gondwanan radiations with those of other areas (Laurentia, Baltica, Siberia, Kazakhstania or China) is made difficult by the lack of precise correlations between the different regional stratigraphic scales. However applying here the recent intercontinental correlations established by Webby (1995) we note a delayed appearance of bivalves in the non-Gondwanan areas.

Another difficulty results from taxonomical problems when trying to better assess diversity. Taxonomic revisions and reevaluations have been made during the last three decades. For example the previous conservative taxonomic approach used for the Ordovician nuculoids has been modified and a clearer picture of the diversity of these primitive faunas has emerged. New data are still strongly needed and we have to carry on actively with taxonomic investigations in order to obtain a more reliable synthesis. However, the available results lead us to make a first attempt in describing the Ordovician bivalves radiations in space and time.

Although obtention of new contradictory data cannot be excluded, the present state of knowledge suggests that the first diversifications occurred as early as Upper Tremadoc times in the western parts of the Gondwanan platforms (Argentina, Morocco, South of France). These were followed by more numerous and simultaneous radiations during Arenig and Llanvirn times in various Gondwanan shelves (Australia, South America, North Africa, South Europe). Higher diversity then occurred in the western part of Gondwanan platforms and on the nearby platforms of Avalonia (Wales). These faunas are dominantly composed of shallow infaunal and semi-infaunal endobyssate bivalves burrowing in clastic sediments. The importance of these first radiations is shown by the presence of various representatives of every order : paleotaxodonts, isofilibranchs and heteroconchs. Although less diversified, pteriomorphs and anomalodesmates are also present. At the genus level a clear endemic distribution differenciates the western and eastern Gondwanan platforms.

The search of the causes for these Ordovician radiations and for their geographical location remains disappointing. Climatic explanations are still weakly argumented. Association with orogenic activity is not substantiated for the Gondwanan areas. Possible interactions with other taxa are not apparent although the life habits of these first bivalves could favor the empty ecospace hypothesis.

During the Caradocian the Gondwanan bivalves faunas decreased dramatically whereas the Laurentian and Baltican ones were rapidly expanding. In the Laurentian and Baltican areas isofilibranchs and pteriomorphs, i.e. semi-endofauna and epifauna, became the most abundant representatives of bivalves. Although less important than in the Gondwanan platforms, minor diversifications of paleotaxodonts occurred with the appearance of the first solemyoids during Upper Whiterockian (a probable correlative of earliest Caradoc).

The Ordovician radiations of the Bivalvia seem to have been a two step process. The first step took place on the peri-Gondwanan shelves with a dominance of infaunal representatives from Tremadoc to Llandeilo. The second step initiated during Caradoc at lower latitudes. It was characterized by the rapid diversification of pteriomorphs which ultimately became the most important component of bivalve faunas during the Silurian. 